\title{
AMERICANIZATION AT THE FACTORY GATE
}

\author{
GERD KORMAN
}

$I^{\prime}$ $\mathrm{N}$ THE decade of World War I the militant wing of the Americanization movement tried to impose its solutions for national vigor and harmony upon welfare and safety programs designed to make industrial relations less exploitive and wasteful. Convinced that the teaching of English and civics was essential for the nation's welfare, militant Americanizers used the war in Europe to launch a campaign for disciplining the loyalties and languages of America's immigrant. This crusade brought them to factories employing large numbers of newcomers. They tried to make existing welfare and safety programs instruments of their crusade and sought to institute practices designed to make immigrant workers learn English and civics. Though they failed to make welfare and safety programs an integral part of the Americanization movement, militant Americanizers helped shape the educational programs large employers of labor were developing for their workers.

The setting for this article is the decade of World War I, when a substantial group of disciplinarians strove to modernize American society. The study examines the interplay between the Americanization movement and developing welfare and safety programs, and evaluates the effects which Americanizers had on these programs.

Gerd Korman is assistant professor at the New York State School of Industrial and Labor Relations, Cornell University. This article is part of a book scheduled for publication later this year. - EdrTor

\section{BEGINNINGS OF THE MOVEMENT}

The twentieth-century origins of the Americanization movement reached back to the 1880's and 1890's when fear about the future composition of America's population and her economic life gripped many native Americans and "old" immigrants. ${ }^{1}$ By the 1900 's, many influential elements had joined the clamor for legislation that would restrict immigration from southern and eastern Europe. Among them were New Englanders spinning out racist arguments, and eugenicists perverting the science of human genetics to fit their preconceptions about immigrants not of "Anglo-Saxon" or "Teutonic" stock. ${ }^{2}$ Numerous attempts were made to pass variations of the literacy test. In 1907 Congress established the Immigration Commission. Under the chairmanship of Vermont's Senator William P. Dillingham, the Commission labored for three years in order to demonstrate that the nation had to adopt effective restrictive legislation to keep out southern and eastern Europeans. ${ }^{3}$

The growing clamor for restricting

\footnotetext{
${ }^{1}$ Merle E. Curti, The Roots of American Loyalty (New York: Columbia University Press, 1946), pp. 74, 184-187; John Higham, Strangers in the Land: Patterns of American Nativism, 1860-1925 (New Brunswick, N.J.: Rutgers University Press, 1955), pp. 1-182.

2Ibid., pp. 131-157; see also Oscar Handlin, Race and Nationality in American Life (New York: Doubleday, 1957), pp. 57-73.

${ }^{3}$ Ibid., p. 79.
} 
immigration around the turn of the century reflected misgivings in many quarters of America about the workings of the long-cherished melting pot inherited from an agricultural economy. ${ }^{4}$ Something was wrong with the entire absorption process, for obviously the nation could no longer create the "American" idealized by St. Jean de Crévecoeur. Faith in a laissez-faire absorption process had been shaken, and many felt it necessary to affect conditions that heretofore had been left to the safekeeping of natural laws supposed to be operative in American society. ${ }^{5}$ In short, those who had lost faith felt it essential to replace an approach symbolized by the melting pot with one that a future generation could symbolize by the pressure cooker.

Conscious participation in the absorption process was possible in a number of areas other than immigration legislation. In the nineteenth century, the public school was usually looked upon as the lubricant for greasing the melting-pot machinery. School officials, however, did little to meet the needs of the first or second generation student; they assumed that somehow education for native Americans was sufficient for all. Toward the end of the century a number of cities in the East and Midwest began to provide evening classes in the English language and in citizenship, but these were usually

"In the crucible of the frontier," wrote Frederick Jackson Turner in 1893, "the immigrants were Americanized, liberated, and fused into a mixed race, English in neither nationality nor characteristics. The process has gone on from the early days to our own." Turner, "The Significance of the Frontier in American History," in George B. Taylor, ed., The Turner Thesis Concerning the Role of the Frontier in American History (Boston: Heath, 1949), p. 11.

${ }^{5}$ Higham, Strangers in the Land, pp. 21, 23, 106-124; Curti, Roots of American Loyalty, pp. 70-71, 183-187, 215-222, 238. of a temporary nature. ${ }^{6}$ Nevertheless, a beginning had been made in expanding the facilities of public school education. In the years to come, all those interested in Americanization continued to look to the schools as one of the most important agencies for teaching English and civics.

The decades of the 1890's and 1900's saw participation in the absorption process gain momentum. The impetus came from social settlement workers, militant nationalists in patriotic societies, and from "public spirited" businessmen in New England. These three groups injected their particular viewpoints into the Americanization movement and competed with each other for leadership.

The settlement workers had not lost faith in the beneficent operation of the melting pot. Instead of breaking with the melting-pot tradition they modified it to mean cultural pluralism. They felt that love and understanding were needed as catalysts in order to make the absorption process operate smoothly. The militant nationalists attempted to change the newcomer into a "good" and "loyal" American by making him conform to their loosely defined ideals and values. Businessmen in New England, fearful for the well-being of their economic order, reluctant to advocate immigration restriction because of their use of immigrant labor, turned to local communities in order to prevent radicals from making serious inroads among immigrant workers. Three years after the founding of the I.W.W., businessmen in New England organized the North American Civic League which sought to improve the protection, dis-

${ }^{8}$ Ibid., pp. 189-190; Arthur M. Schlesinger, The Rise of the City (New York: Macmillan, 1933), p. 66; Wisconsin Journal of Education, vol. 10, October 1880 , p. 432; Higham, Strangers in the Land, pp. 235-236; Milwaukee Sentinel, March 8, 1893; Milwaukee Germania Abendpost, Oct. 8, 1897. 
tribution, and education of immigrants. The League initially stressed language education and civics but, after the upheavals at Lawrence, Massachusetts, and Paterson, New Jersey, its emphasis shifted to a program of industrial spying, strike breaking, and undercutting recruitment drives by organized labor and radical groups. ${ }^{7}$

Few of those concerned with the immigrants' problems or America's problems with the immigrants would have denied that teaching English to immigrants was an important aspect in effecting the absorption process. Militant nationalists and the League insisted that the teaching of English was an essential element in order to Americanize newcomers. Social settlement workers viewed language programs as desirable tools for helping the alien adjust to his urban and industrial surroundings. Private immigrant groups, concerned with the protection and distribution of countrymen just arriving, often included educational programs that stressed the teaching of English. ${ }^{8}$

All of these groups agitated for an expansion of public school facilities, and by 1914 had made some progress in this direction. The federal Bureau of Naturalization and Immigration made the public schools the focal point of its own

${ }^{7}$ Higham, Strangers in the Land, pp. 121-122, 236, 240, 250-254; Curti, Roots of American Loyalty, p. 238; Edward George Hartman, The Movement to Americanize the Immigrant (New York: Columbia University Press, 1948), pp. 3136, 38-63, 88-90; United States Census, 1910, vol. 2, p. 853; National Convention of the Socialist Party, Proceedings, 1908: pp. 313-314, 1910, pp. 20, 307, 1912, pp. 237-242; Ira Kipnis, The American Socialist Movement, 1897-1912 (New York: Columbia University Press, 1952), pp. 272-274. During the war, the Committee on Public Information "most consistently applied" the view of the social settlement workers. Higham, Strangers in the Land, p. 252.

sIbid., p. 236; Hartman, Movement to Americanize the Immigrant, pp. 25-36.
Americanization program. ${ }^{9}$ Local communities expanded school facilities for educating immigrants. In Milwaukee after 1910, for example, evening classes in the public school were supplemented by night classes in social centers under the jurisdiction of an extension division of the city's school board. In February 1914, three such centers offered language classes to assist immigrants to become naturalized Americans. In the same year, the board began similar programs in ten schools located in immigrant neighborhoods. ${ }^{10}$ This work in Milwaukee was similar to activities going on in New York and Chicago. ${ }^{11}$

To enthusiastic proponents of Americanization, however, the nation's schools by themselves could not cope with the problem. They claimed that the teaching of English and civics by most states and municipalities fell far short of the need. They charged that legislators and school officials had little understanding of the problems and functions of adult education. Texts were carelessly selected from among books that in themselves were usually poorly prepared for teaching English to adult foreigners. The time and place of evening school classes was too often determined by factors other than the need of immigrant workers to indicate serious concern and interest in the problem. Specialization in the super-

${ }^{9}$ Richard M. Campbell, commissioner of the Bureau of Naturalization and Immigration to Peter Roberts, Washington, Jan. 11, 20, 1916 , Case File, 27671/614, National Archives; H. H. Wheaton, "Survey of Adult Immigrant Education," Immigrants in America Review, vol. 1, June 1915, pp. 51-53.

${ }^{10}$ Milwaukee Leader, Feb. 3, 1914; broadside issued by the Social Center Publicity Department of the Milwaukee Board of Education, in the newspaper scrapbook of the Board; Wisconsin State Council of Defense, Minutes of Meetings, May 25, 1917, Mss., Box 3, Series 76/1/10, Wisconsin Archives, WSHS.

${ }^{11}$ Higham, Strangers in the Land, pp. 235-236. 
vision of public evening education for immigrants was still a novelty practiced by only Rochester and Cleveland; in New York, Boston, Philadelphia, Providence, Buffalo, Chicago, and Detroit the night programs were supervised and taught by administrators and teachers of day school programs. These men, it was charged, had too many daytime responsibilities to give the night programs the attention they deserved. ${ }^{12}$

Beset with these difficulties, and knowing that attendance in public schools was voluntary, some private groups advocating Americanization sought to institute English-language classes in factories. This aspect of the Americanization movement consisted of two phases. The first phase, begun under the auspices of the YMCA and interacting with the industrial safety campaign, was not a part of the movement's militant wing. The second phase got under way in 1915, and this drive was an integral part of the Americanization crusade.

The remainder of this article traces these two phases in a variety of settings in order to show in detail the different, but often interacting, ways by which reformers of industrial relations and Americanizers tried to reach the immigrant.

\section{EARLY PROGRAMS AND THE YMCA}

The first phase was started by Peter Roberts, a Welshman who had spent some years among immigrants in Pennsylvania's coal fields. In 1907, as the new head of the industrial department of the national council of the YMCA, he

\footnotetext{
${ }^{12}$ Peter Roberts to Raymond Crist, deputy commissioner of the United States Bureau of Naturalization and Immigration, New York, Jan. 6, 1916; Roberts to Campbell, Jan. 17, 1916, Case File 27671/614, National Archives; H. H. Wheaton, "Survey of Adult Immigrant Education," pp. 51-53.
}

launched the "Y's" program for immigrant workers. The geographic focus of his drive was in an area which Roberts called the "immigrant zone"; that industrial region bounded on the west by the Mississippi and on the south by the Potomac and Ohio rivers. By 1915, the "Y" had about 500 branches operating in this region with 300 of them engaged in educational work for immigrants. The program had recruited about 1900 language instructors from various walks of life: men who lived in " $Y$ " homes; Bible-class members; employees of industrial plants; a few professional men; students in colleges, universities, and seminaries; businessmen; and public servants. These instructors were provided with material Roberts had worked out for teaching English to immigrant workers and with literature selected by the "Y" from such organizations as the Sons of the American Revolution, the National Temperance League, and the National Safety Council. ${ }^{13}$

In establishing English-language classes for factory employees, the YMCA operated under a number of handicaps. In the first place, many workers considered the "Y" a tool of employers. Second, many immigrants were Catholic while the "Y" was a Protestant organization. Roberts strove to overcome this difficulty by eliminating proselytizing, but numerous employers continued to feel that their Catholic workers were reluctant to participate in "Y" activities. ${ }^{14}$ Third, the

${ }^{13}$ Edith T. Bremer, "Development of Private Social Work with the Foreign-born," Annals of the American Academy of Political and Social Science, vol. 262, March 1949, p. 140; Peter Roberts, "The YMCA Teaching Foreign-Speaking Men," Immigrants in America Review, vol. 1, June 1915, pp. 18-19, 21; William M. Leiserson, Adjusting Industry and Immigrant (New York: Harper, 1924), pp. 121-122.

${ }^{14}$ National Conference on Americanization, Proceedings, 1918, pp. 20-23; Peter Roberts, The 
" $Y$ " included sermons on temperance and patriotism. These practices probably alienated some immigrants. Temperance propaganda could not have sat well with immigrants who traditionally drank wine and beer. Lectures accompanied by patriotic songs about the blessings of America's political and economic opportunities often suffered by the comparisons immigrants made with the realities of their situation. One Italian workman, for example, listened to the song "America" and asked his instructor to explain to him the meaning of the words "sweet land of liberty." At the end of the explanation, the workman simply said, "Teacher, the song is making a mistake."15

In spite of the handicaps, the "Y" was more successful than other private groups in establishing and participating in English-language classes in industry. Roberts had the advantage of working for an organization that had the endorsement of powerful employers. Toward the end of the century, an increasing number of companies permitted noon-day factory meetings to be held by " $Y$ " representatives. Roberts' own enthusiasm and ability helped to convince employers of the importance of his program. He knew how to adjust his work to developments occurring within the industrial world. His emphasis on the practical was amenable to the needs of large corporations. With the proper adjustments, his introductory lessons could be made to fit welfare and safety programs of individual companies.

Roberts' language-teaching technique

New Immigration (New York: Macmillan, 1912), p. 320. See also, Howard K. Beale, "Teaching English to Foreigners," and "Y.M.C.A. English Class," undergraduate themes done in 1918 and 1920 , Beale Mss. I am indebted to the late Mr. Beale for permitting me to see these.

${ }^{15}$ Society for Italian Immigrants, Annual Report, 1913, pp. 11-12. frowned on irrelevent content and abstract teaching methods. He divided his curriculum into three interrelated parts - introductory, intermediate, and advanced. The intermediate and advanced courses focused on reading lessons in history, geography, and civics; the advanced course of thirty-five lessons was devoted almost entirely to the latter subject as preparatory work for naturalization and good citizenship. The most significant course was the introductory one of thirty lessons, since few immigrants actually went beyond this stage. This course stressed the practical and necessary: the first ten lessons were devoted to common phrases used at home; the next ten to teaching words related to factory employment; the last ten stressed words pertinent to buying, selling, traveling, and trading. The lessons were to be taught by acting out words and sentences. ${ }^{16}$ One " $Y$ " worker all but undressed himself in order to teach English equivalents for various pieces of clothing. ${ }^{17}$

The purpose of these introductory lessons, according to Roberts, was one of social service. He spoke of "coming Americans" and tended to stay away from the label "Americanization." He did not belong to the militant nationalists but, like many other social settlement workers, he felt that the "new immigrant" could become a dangerous problem if left to himself. $\mathrm{He}$ was convinced that men like himself had to go to the immigrant's home and place of work if newcomers were to be exposed to what he considered healthy American influences. "Shun the foreigner, leave him to himself, let him alone in dirt and disease," said Roberts in 1915, "and unseen by an appreciative

\footnotetext{
${ }^{16}$ Peter Roberts, "Y.M.C.A. Teaching ForeignSpeaking Men," pp. 20-21; Peter Roberts, The Problem of Americanization (New York: Macmillan, 1920), pp. 97-107.

${ }^{17}$ Beale, "Teaching English to Foreigners."
} 
eye he will simply drift. We would do the same." 18

Among the companies which introduced the Roberts' method were the International Harvester Company, the United States Steel Corporation, and the Ford Motor Company. Each of these industrial firms incorporated the " $\mathrm{Y}$ "'s program for immigrant workers with their welfare and safety efforts and integrated it with their attempts to discipline their employees.

The Roberts' method was introduced at International Harvester in 1910. The Chicago "Y" presented the Roberts' method to a welfare committee composed of production personnel, welfare workers, and industrial safety workers. The "Y" stressed the fact that the lessons were practical and included material that gave the "foreigners the first necessary English required in getting a job and taking hold." 19 The program was favorably received by some of the superintendents who immediately viewed it in terms of the activities already taking place in the company. They believed that the Roberts' method would "be a real aid to the efficiency of the safeguarding against injury and lastly, although by no means least, in the improved relations of the men to the community." 20 The then chief social secretary for the company and secretary of the welfare board also endorsed the Roberts' method. She argued that English classes could maximize the immigrant worker's potential in the company and made it plain that she considered this

\footnotetext{
${ }^{18}$ Roberts, "Y.M.C.A. Teaching Foreign-Speaking Men," pp. 20-21. Roberts, New Immigration, pp. viii, 306-307. By 1920 he wrote a book entitled The Problem of Americanization, but its theme was opposition to militancy and coercion. Ibid., passim. 29.

${ }^{10}$ Harvester World, vol. 2, December 1910, p.

${ }^{20}$ Ibid., vol. 2, September 1911, p. 28. See also ibid., vol. 5, March 1914, p. 30.
}

another area in a welfare program directed at improving the efficiency of the company's work force. ${ }^{21}$

In 1911 English-language education began at the Weber Works of International Harvester. "An important line in the interest of welfare work has been undertaken recently," explained the Harvester World, "... and is now tried out... and, so far with signal success." 22 The "Y" was conducting night classes "for the benefit of 'coming Americans' among the Greeks and Lithuanians." These classes were attended by men and women who sought to prepare themselves for naturalization. Officials of the company claimed it was most gratifying to them to see that class attendance had not wavered in spite of the fact that the " $Y$ " began to charge a nominal fee after the first ten free lessons. $^{23}$

\section{EARLY PROGRAMS AND MANAGEMENT}

The "Y" 's jurisdiction over these classes did not last long. By January 1912, they had been placed under the control of the superintendent of the Weber Works. He had worked out a course "... on the line of a series of lessons dealing with the work of the plant." 24 This meant that the lessons at the Weber Works and, by March 1912, at two other Harvester plants in Chicago stressed shop discipline, welfare work, and safety. It was the aim of the company, said one of its spokesmen, that the "embryo American, and employee of the works should at one and the same time learn to speak English correctly and also have impressed upon him the rules he should follow while in and around the works." The

\footnotetext{
${ }^{21}$ Ibid., vol. 3, January 1912, p. 32.

${ }^{22}$ Loc. cit.

${ }^{23}$ Loc. cit.

${ }^{24}$ Loc. cit. See also ibid., vol. 3, March 1912, p. 31 .
} 
immigrant was expected to learn how to "think and talk intelligently about all the important operations in the works, in his own department as well as in other departments." Immigrants were to become "good American citizens and good employees." 25

Two lessons of the company's special English-language curriculum stressed discipline, welfare, and safety work in particular. The first lesson entitled "General" was devoted exclusively to matters of discipline.

I hear the whistle. I must hurry.

I hear the five minute whistle.

It is time to go into the shop.

I take my check from the gate board and hang it on the department board.

I change my clothes and get ready to work.

The starting whistle blows.

I eat my lunch.

It is forbidden to eat until then.

The whistle blows at five minutes of starting time.

I get ready to go to work.

I work until the whistle blows to quit.

I leave my place nice and clean.

I put all my clothes in my locker.

I go home. ${ }^{26}$

Lesson One was followed by a series of others devoted to various parts of a plant and to specific tools. Like the first one, they dealt with the familiar in line with the Roberts' method. ${ }^{27}$ One of them com-

${ }^{25}$ Ibid., p. 30. See also ibid., vol. 3, January 1912, p. 32.

${ }^{20}$ Ibid., vol. 3, March 1912, p. 31.

${ }^{27}$ For other uses of the familiar in teaching English to foreigners, see for example: Lillian P. Clark, Federal Textbook on Citizenship Training (Washington: United States Department of Labor, 1924), passim; Issac Price, The Direct Method of Teaching English to Foreigners (New York: Noble and Noble, 1909), passim; Sarah R. O'Brien, English to Foreigners (New York: Houghton Mifflin, 1909), passim; William E. bined elements of the welfare and safety program under way at the company.

The Employee Benefit Association is composed of the employees of the International Harvester Company.

When you are sick or hurt report to your timekeeper and the doctor at once.

If you get sick at home send word at once to your timekeeper or your foreman.

You are paid one half of your regular daily earnings for every day you are sick after one week.

While you are sick do not leave the city without first seeing the doctor and telling him about it.

The doctor takes care of all accidents that happen in the works.

You should call on the doctor when you are able; do not wait for him to call on you.

When the door of the doctor's office is closed, knock and wait for him to say, 'come in,' before you open the door.

Do not try to take slivers out of the hand or cinders out of the eye for yourself or another, but go directly to the doctor's office.

When you are hurt in the works, you will be paid one half wages for all the time you are disabled, provided you report the accident at once to your timekeeper and the doctor.

No benefits will be paid if you are hurt while scuffling or fooling.

No benefits will be paid if you are hurt or get sick as a result of having been drinking. ${ }^{28}$

The United States Steel Corporation adopted the Roberts' method in a man-

Chancellor, Reading and Language Lessons for Every School (New York: American Book Company, 1904), passim.

${ }^{28}$ Harvester World, vol. 3, March 1912, p. 31. 
ner similar to the one used at International Harvester. In 1908 U.S. Steel launched its safety program. A committee of safety was established to provide a clearing house for safety and general welfare information for the many subsidiaries in the corporate organization. ${ }^{29}$ After 1910 the committee published a bulletin entirely devoted to matters of safety, welfare, and sanitation. ${ }^{30}$ Before World War I, the bulletin did not explicitly refer to Americanization but it did present examples of lesson plans being used in English-language classes. The lessons were based on the Roberts' method; Roberts himself had worked closely with U.S. Steel in the initial stages of the language program. These lessons were entirely devoted to safety matters. ${ }^{31}$

The Ford Motor Company had also introduced this type of language education for immigrants. At Ford, however, the beginnings occurred around the time when militant Americanizers called for education in civics and the rapid naturalization of immigrants. ${ }^{32}$ These features of Ford's program for immigrants were thus associated with the militant Americanizers, but in fact the language program, as it existed at International Har-

\footnotetext{
${ }^{29}$ United States Steel Corporation, Committee of Safety, Bulletin, October 1910, n.p.

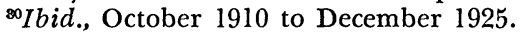

${ }^{\mathrm{s}}$ Roberts, Problems of Americanization, p. 99; United States Steel Corporation, Committee of Safety, Bulletin, November 1913, p. 8.

${ }^{32}$ Immigrants in American Review, vol. 1, September 1915, p. 6; Hartman, Movement to Americanize the Immigrant, p. 129. The Committee for Immigrants in America had been instrumental in beginning Detroit's drive. Esther E. Lape, "The English First Movement in Detroit," Immigrants in America Review, vol. 1, September 1915, pp. 46-50; Allan Nevins and Frank Ernest Hill, Ford: the times, the man, the company (New York: Scribner, 1954), vol. 1, pp. 532-545, 557; vol. 2, 340-341; John R. Lee, "So-called Profit Sharing System in the Ford Plant," Annals of the American Academy of Political and Social Science, vol. 65, May 1916, pp. 297-310; Higham, Strangers in the Land, p. 248.
}

vester and at the United States Steel Corporation, was tied much more closely to safety and welfare work than it was to civics and naturalization. ${ }^{33}$ By 1914 Ford had one of the nation's most elaborate welfare programs, similar in many ways to the program at International Harvester, except that at Ford welfare work was directly tied to hiring and firing practices, and to wage increases. ${ }^{34}$ The safety campaign had come to Detroit later than it had to some other industrial areas, but it had arrived before 1914; indeed, when militant Americanizers launched their language campaign in Detroit in 1915, employers used safety committees as one of the means for propagandizing the language drive. ${ }^{35}$ Safety men had concerned themselves with the immigrant before English-language education was begun. ${ }^{36}$ Robert Shaw, safety engineer for the company in 1917, claimed that they had felt that instruction in the English language would help them in their activities and had urged the use of such education. Before Ford established its English School in May 1914, the company had issued a safety bulletin in forty-two different languages. "We had the problem of...different nationalities and the first thing we decided was that we would use only the English language. Every sign, every danger sign or construction notice," claimed Shaw, "was put into English and the first thing we did was to start an English school. It has solved the bad

${ }^{39}$ Nevins and Hill, Ford, vol. 1, pp. 532-545.

3I Ibid.: vol. 1, pp. 513-515, 551-554, 556, vol. 2, pp. 332-340.

${ }^{25}$ Lape, "The English First Movement in Detroit," p. 46

${ }^{30}$ Nevins and Hill, Ford, vol. 1, pp. 520-522; Robert H. Shaw, safety engineer, Ford Motor Company, in National Safety Council, Proceedings, 1916 , p. 225. See also, ibid., 1917, p. 795, for comments of W. Ernest William, safety engineer of the Packard Motor Company. 
problem in regard to our safety work."37 Language education included lessons similar to those at U.S. Steel and at International Harvester. Safety, shop discipline, and other aspects of company welfare programs, including material stressing Ford's benevolence, were all subjects built into language lessons. ${ }^{38}$ This similarity reflected the influence of Peter Roberts. He trained volunteer teachers in the use of his methods and designed lesson plans to meet the needs of the Ford organization. ${ }^{39}$

Thus the first phase of language education for immigrants in factories emerged from an industrial context. The classes were not introduced either because of fear of the immigrants effect on America or for making his adjustment to America less disturbing. The classes grew out of the same demands that had resulted in welfare and safety activities and were an integral part of these programs. The classes concerned themselves primarily with only one sphere of the immigrant's surroundings: factory life. YMCA workers at International Harvester and U.S. Steel encountered situations demanding that they work within the framework set by the production personnel. Instructors recruited by the YMCA may often have entered Englishlanguage classes with the noblest of ambitions and a genuine urge to teach the immigrant basic language skills. They were not interested in, if not outrightly hostile to, the content of an English-language curriculum that an industrial

\footnotetext{
${ }^{37}$ Ibid., 1917, p. 236.

${ }^{38}$ Nevins and Hill, Ford, vol. 1, p. 557.

${ }^{39}$ Henry Ford to Detroit YMCA, Detroit, Dec. 2, 1914 in The Association Among 59 Nationalities in File 27671/614, Records of Immigration and Naturalization Service, National Archives. For the "Y" 's brief account of Roberts' work at Detroit, see loc. cit. Nevins identifies Peter Roberts only as "a Dr. Roberts." Nevins and Hill, Ford, vol. 1, p. 557 .
}

organization wanted taught. To them the classes represented a device to help the immigrant cope with America, and the interests of an industrial organization were simply too narrow to satisfy them. It required stubbornness and resourcefulness on the part of such a "Y" worker to overcome the pressure of companies. In Chicago at a "Y" class of Illinois Steel, a subsidiary of U.S. Steel, it took all the ingenuity of an instructor to convince foremen visiting his class that the company's "shop" lessons were of little use or interest to the men and women seeking to learn English for general use. ${ }^{40}$

\section{THE WAR YEARS}

The war in Europe gave Americanizers the opportunity to give their movement a sense of urgency. The wrangle over the rights of neutrals began in the first year of war and made American participation in the conflict a possibility. When, in May 1915, a German submarine brought death to over a hundred Americans by sinking the Lusitania, cries for the nation's entry into war against Germany were heard in many quarters of the land. ${ }^{41}$ Americanization now became synonymous with national interest and with national defense. The opportunity was at hand to mount a campaign for disciplining loyalties and languages; in short, for disciplining American nationalism. And this opportunity came at a time when the spread of welfare work and other practices for systematizing human relations in factories gained momentum, thus creating a condition in industry seemingly conducive to militant Americanizers.

One of the most influential persons in

\footnotetext{
${ }^{40}$ Beale, "A YMCA English Class" and "Teaching English to Foreigners."

${ }^{41}$ Carl Wittke, The German-Language Press in America (Lexington: University of Kentucky Press, 1957), pp. 252-254.
} 
the Americanization crusade was Frances Kellor. She injected into Americanization a zeal for making the nation's economy and body-politic function more efficiently. Miss Kellor began her public service career as a lawyer turned "social worker." In 1904, she published an analysis of employment offices in New York City, paying particular attention to immigrants and to the chaotic manner in which labor was distributed. In the next few years, she worked for municipal and state agencies investigating the many social problems confronting the urban communities. She soon became an authority on urban immigrants and immigrant legislation. By 1906, she had already become influential in shaping Theodore Roosevelt's views on matters of immigration. ${ }^{42}$

In the midst of her activities as a public servant for the New York Commission on Immigration, Miss Kellor obtained the support of two wealthy New Yorkers, Frank Trumbull and Felix Warburg, for Americanization work. In 1909 they established a branch of New England's North American Civic League, but from its founding the New York group's basic approach to Americanization differed from that of the parent body. The New Yorkers had a genuine interest in changing general environmental conditions throughout the nation. Between 1912 and 1914, the differences between the parent body and the New Yorkers increased. The activities of the I.W.W. at Lawrence, Paterson, and elsewhere in the Northeast heightened the fear of the League about the effects of radical foreign-language organizers among immigrants. Subsequently, the League turned to spying and

\footnotetext{
${ }^{42}$ Higham, Strangers in the Land, pp. 239-241; Frances Kellor, Out of Work: A Study of Employment Agencies, Their Treatment of the Unemployed, and Their Influence upon Homes and Business (New York: Putnam, 1904), passim.
}

other tactics in order to block strikes and union activity among the foreign-born. At the same time Miss Kellor became an enthusiastic worker for the Progressive party; she served as the head of its research and publicity department. Early in 1914, the New York branch of the League broke with the parent body and established the Committee for Immigrants in America. Miss Kellor became vice-chairman and its guiding light. In 1915, she became editor of Immigrants in America Review, a journal published by the committee and devoted to Americanization. Miss Kellor now had an organization and a journal through which she could hope to marshall national opinion. In this effort she had the support of a number of well-known intellectuals committed to Roosevelt's New Nationalism; Herbert Croly, Walter Lippmann, and Felix Frankfurter served on the advisory board of Immigrants in America Review. 43

The absence of a clearing house for centralizing Americanization activities gave the Kellor group the opportunity for filling the void. With the help of the United States Bureau of Education, the committee created, staffed, and financed the Division of Immigrant Education within the Bureau. This division became the federal agency through which the committee obtained official endorsement for much of its propaganda.44 In May of 1915 the United States Bureau of Naturalization and Immigration held a mass celebration of naturalization ceremonies in Philadelphia; President Wilson graced the occasion and chose it for his "Too

\footnotetext{
${ }^{43}$ Hartman, Movement to Americanize the Immigrant, pp. 56-63, 91-97; Immigrants in America Review, vol. 1, March 1915, p. 102.

${ }^{44} I b i d$., vol. 1, September 1915, pp. 3-4, 15, 30-32; Hartman, Movement to Americanize the Immigrant, pp. 97-100, 112-114.
} 
Proud to Fight" speech.45 Between the Philadelphia celebration and July 4 the committee made Independence Day, 1915 , the occasion for mass celebrations of naturalization in 100 American cities. The success of the Independence Day campaign helped the committee become established as the nation's organization leading the crusade for Americanization. ${ }^{46}$

Until 1915, Miss Kellor was a nationalist of the Croly-Roosevelt persuasion. She was an energetic advocate for systematizing industrial production, distribution, and factory personnel. She looked toward the day when America's population would be more or less homogeneous in its loyalties to the state, and when the country's economy would be so regulated that conflict between labor and capital would be reduced to a minimum. She preached, as John Higham has noted, social welfare and national discipline. ${ }^{47}$

The official statement of purpose issued by the committee reflected these views. It considered Amercianization a domestic immigration policy, which dealt with the following problems: the reduction of unemployment; the elimination of discriminatory state and municipal legislation; the improvement of the immigrants' standard of living; the distribution of alien workers according to the needs of the economy and the abilities of the immigrants; the protection of immigrants, particularly their savings; finally, the improvement of educational facilities for newcomers, including opportunities for industrial training. ${ }^{48}$ Two parts of the Review also focused attention on

${ }^{45}$ Ibid., pp. 107-111; Immigrants in America Review, vol. 1, September 1915, pp. 303-332.

${ }^{48}$ Loc. cit.; Hartman, Movement to Americanize the Immigrant, pp. 112-124.

${ }^{47}$ Higham, Strangers in the Land, p. 239.

${ }^{48}$ Immigrants in America Review, vol. 1, March 1915, pp. 3-15, 17-86. these problems. "The Record of Progress" pointed to activities in the area of unemployment, legislation, and education. The book review section listed and discussed books pertinent for an understanding of the problem raised by the formal policy statement. These included books concerned with industrial service work. 49

\section{MILITANT NATIONALISM}

With the first issue of Immigrants in America Review, in March 1915, however, it was plain that the militant nationalist in Miss Kellor was coming to the fore. The need now, she said, was the "conscious effort to forge the people of this country into an American race that will stand together for America in time of peace and war." By September she sounded frightened about the potentialities of un-Americanized immigrants. "Because of our lack of patriotism, efficiency, and consideration we have failed to inspire our better conditioned immigrants and their sons with a love for this country which supplants that of other countries." This failure was a serious weakness, for immigrants and often their children had deep attachments for the mother country. It was "more widespread than we know," she claimed, and warned that "in case of war we would have in this country if not actual traitors, a division of forces such as would make a victory precarious in any prolonged warfare." In January 1916, she cried that America faced a crisis. The big problem was not "whether we need a larger army and navy, but whether we shall have a United America back of that army and navy, and whether America, with her

${ }^{40}$ Ibid.: vol. 1, March 1915, pp. 90-94, June 1915 , pp. 76, 87, 94, September 1915, pp. 98, 108; vol. 2, June 1916, pp. 110-111. 
many races and divided allegiances will survive as a great nation." 50

Miss Kellor's militancy and one-sided approach to Americanization evoked sharp criticism in some quarters, and in January 1916, she responded by printing an article written by Horace Kallen, a social psychologist, who had been developing his concepts of cultural pluralism since the early years of the century. ${ }^{51}$ Kallen's piece was a careful statement on the evolution and meaning of such American ideals as liberty, union, and democracy. $\mathrm{He}$ attacked militants like Miss Kellor because they engaged in "vicious abstractionism," a term Kallen borrowed from William James. Even T.R., maintained Kallen, would hardly consent to a marriage between his son and a Negress in the interest of New Nationalism. The whole issue of double loyalties, maintained Kallen, had got out of hand because of people who did not distinguish between treason and differences in values and beliefs. He charged that those obsessed with this issue were distorting the meaning of American democracy. "In essence democracy involves not the elimination of differences but the perfection and conservation of differences. It aims through union, not at uniformity but at variety." 52

The editor had, however, moved too far towards militant nationalism to take heed of Kallen's comments. By 1916, the militant nationalists rather than the so-

${ }^{50}$ Ibid.: vol. 1, March 1915, p. 15, September 1915, pp. 3, 4-5, January 1916, p. 3.

${ }^{51}$ Kallen told the author in 1962 that he began to develop his ideas about cultural pluralism just after the turn of the century. Kallen was then studying philosophy under William James at Harvard. See also Kallen's Culture and Democracy in the United States (New York: Boni and Liveright, 1924).

${ }^{52}$ Kallen, "The Meaning of Americanism," Immigrants in America Review, vol. 1, January 1916, pp. 12-19. cial settlement workers were giving Americanization its main direction. In that year, Miss Kellor published her book, Straight America in which she espoused an "America First" position on the question of Americanization. ${ }^{53}$ This was the viewpoint that she attempted to spread among the nation's employers.

Throughout 1915, Miss Kellor considered the place of industry in Americanization work. In the spring she called on the nation's chambers of commerce to add "industrial assimilation of the immigrant workmen" to their programs in the hope that the chambers of commerce could assist in changing the alien's feeling that he was an "outsider, on a different footing from the American workmen." She called for a program of civics and English and measures providing for equality of opportunity to newcomers. This emphasis soon changed. After the successful July 4 celebrations, she stepped up her campaign to recruit local chambers of commerce, trade associations, and industrial plants. On the inside cover of the Immigrants in America Review, published after the Fourth, she addressed "businessmen" for the first time as a group who ought to join the crusade. Miss Kellor argued that Americanization would increase the efficiency of immigrant employees, prevent accidents, and help "businessmen" understand the needs of immigrants. It would "eliminate industrial misunderstanding and...maintain our American standard of living."

During the winter, Miss Kellor and three other leading members of the Committee for Immigrants in America took their campaign into the organizational structure of the United States Chamber of Commerce. The Chamber established an Immigration Committee with Frank Trumbull, chairman, William F. Mor-

\footnotetext{
${ }^{53} \mathrm{Higham}$, Strangers in the Land, pp. 242-244.
} 
gan, treasurer, and with Miss Kellor, assistant to the chairman. The Immigration Committee became an effective organ for the Kellor group, although this was not at first generally known. ${ }^{54}$ The Deputy Commissioner of the Bureau of Naturalization and Immigration had not recognized the linkage until he was told about it by the Chamber's Immigration Committee. ${ }^{55}$

The Immigration Committee of the Chamber tuned in on the industrial service movement that was gaining momentum in these years. "The nationwide Americanization movement," the committee explained to members of the Chamber of Commerce, "is part of the present day trend toward humanizing industry. It aims to take what is commonly called welfare work out of paternalism and make it a part of legitimate business organizations everywhere.... There is no agreement among American employers now as to the extent and manner of its organization or where it really belongs. There are no recognized standards. What we need is to extend scientific methods to the human phase of industrial organizations and give welfare work a more definite place and recognized standards. ..."56

By linking Americanization to the "trend toward humanizing industry,"

${ }^{54}$ Immigrants in America Review: vol. 1, June 1915, pp. 2, 9, September 1915, p. 2, January 1916, p. 86; Hartman, Movement to Americanize the Immigrant, pp. 113-132.

${ }^{55}$ Richard M. Campbell, commissioner of the Bureau of Naturalization and Immigration to Eliot H. Goodwin, secretary, United States Chamber of Commerce, August 18, 1917, Sept. 8, 1917, Frances A. Kellor to Campbell, Sept. 5, 1917, Bureau of Naturalization and Immigration, Case File, 27671/1832, National Archives.

${ }^{5 B}$ Report of the Committee on Immigration of the Chamber of Commerce of the United States of America, Fifth Annual Meeting, 1917, p. 2, in Bureau of Naturalization and Immigration, Case File, 27671/1832, National Archives.
Miss Kellor's group demonstrated an appreciation of the strategic role that autocratic industrial organizations could play in the crusade, and at the same time accepted one of the fundamental underpinnings of that "humanizing trend." Miss Kellor applauded the actions of Detroit employers, who were among the first to use their coercive power to make immigrants attend English-language and civics classes in the public schools or factories. In 1915 she praised the Packard Motor Company for making attendance a condition of promotion. Indeed, by 1916 she was prepared to argue that such coercion was perhaps one of the few ways to force immigrants into educational programs advocated by Americanizers. ${ }^{57}$ And, as she supported this use of power so too did she accept one of the basic assumptions behind the "humanizing trend." In January 1916, she gave this explanation of the significance of Americanization for industry:

It will mean first of all industrial peace. So long as our industrial communities are made up of large groups of unAmericanized immigrants, without the English language, without understanding American conditions, too helpless to bring their grievances to the attention of their employers, too ignorant to force them in legitimate ways if they were not offered, able to understand only the radical agitators addressing them in their own languages - [sic] just so long will the industrial history of America be blotted out by Calumets, Ludlows, Lawrences, and Wheatlands. The road to American citizenship, to the English language, and an understanding of American social and political ideals is the road to industrial peace. Even now in peace, our country is honeycombed with industrial strife, disorder and disputes involving the destruction of life and property. ${ }^{58}$

\footnotetext{
${ }^{57}$ Immigrants in America Review: vol. 1, September 1915, p. 16, January 1916, p. 6.

${ }^{58}$ Ibid., p. 4.
} 
In the years from 1916 to 1918 , Miss Kellor and her supporters intensified their campaign to convince employers that Americanization was part of the "humanizing" efforts being carried on by industrial organizations. In March 1917, the Committee for Immigrants in America created still another committee. This was the Committee on Industrial Engineering staffed by numerous experts recruited from universities and industry. The group published its own bulletin which concerned itself with industrial service work. These were subjects that the Immigrants in America Review, now defunct, had always stressed. At the same time, the Immigration Committee of the Chamber of Commerce continued its own publicity drive, and at the end of 1917 claimed marked success in establishing factory classes for immigrants. In the spring of 1918, as America entered its second year of war, the Kellor group centralized much of its work by operating through federal agencies. It expanded the facilities of the Bureau of Education. It enlisted the support of the Department of Interior and was able to convince the National Council of Defense, a war-time agency, to accept its Americanization program. ${ }^{59}$

\section{MANAGEMENT RESPONSE}

Industry responded to Miss Kellor's campaign on its own terms. Among the

${ }^{59}$ Ibid., vol. 1-2, passim; Frank P. Walsh of the United Mine Workers saw clearly the relationship between Kellor's Americanization drive and the efforts to humanize the industry. He also sharply attacked Kellor's group for not including unions in its campaign. United Mine Workers Journal, vol. 25, Feb. 3, 1916, p. 7; United States Chamber of Commerce, Immigration Committee, Bulletin, Feb. 15, 1917, March 1, 1917, April 15, 1917, June 15, 1917, Dec. 15, 1917, Jan. 2, 1918, Bureau of Naturalization and Immigration, Case File 27671/1832, National Archives; Hartman, Movement to Americanize the Immigrant, $\mathrm{pp}$. 165-166, 187-205. safety inspectors, the budding employment managers and the visiting nurses, and other men and women in the forefront of safety and welfare work Miss Kellor's views made slow headway. Before 1915, the link between safety and Americanization was rarely discussed in the conferences of the National Safety Council, but in subsequent years discussion of the linkage increased as militant Americanizers tried to persuade the Council to use its educational bulletins for safety and health to compel immigrants to learn English. Dr. J. W. Schereschewsky of the United States Public Health Service objected to translations of such bulletins into foreign languages. Speaking in the fall of 1917 he said: "When we consider educational measures among workers, we ought not to give them the opportunity for perpetuating their native speech, but make them understand that now is the time for them to become true American citizens and learn to speak the language of this country."'60

W. S. Tenor of the American Wire and Steel Company in Cleveland supported Schereschewsky's position on language because of conditions in his company. $\mathrm{He}$ had published, he said, safety literature in various languages, but on one occasion this led to a strike because "we omitted a certain language." This omission, he claimed, led to national animosities as the excluded group was ridiculed by other language groups. They said "why did the company not think of putting your language in the book" and insisted that the excluded group had no right to national aspirations. For that and other reasons, said Tenor, "it is best to confine work to

${ }^{60}$ National Safety Council, Proceedings, 1917, p. 235. For an example of establishing a linkage between Safety and Americanization before 1915, see ibid., 1912, pp. 13-15. 
English and we have pretty well abandoned the idea of using any other languages." 61

J. B. Douglas, of the United Gas Improvement Company in Philadelphia, chairman of a meeting of the Public Utilities Section of the Council, expressed his cautious support of Americanization. He referred in particular to a ruling of the Pennsylvania Department of Labor and Industry requiring foremen engaged in hazardous work to speak and understand the language of their workers. "While this ruling may be termed progressive, I am in doubt as to how it will work out in practice." "It does point, however," said Douglas, "to the importance of employees being able to speak English and I firmly believe that just as soon as labor conditions will permit all progressive employers will give the 'Americanization' of their employees the attention it undoubtedly deserves." 62

There were others who pleaded for using safety and health literature as teaching devices for Americanization. Charles B. Milner of the Hammermill Paper Company of Erie, Pennsylvania, urged that special cards, printed in the immigrant's languages, be tacked to bulletin boards; these cards should tell immigrants to have English bulletins translated for them.63 Charles A. Prosser, director of the United States Board of Vocational Education, agreed that safety bulletins could "be made a very practical drill in English." 64 The most outspoken advocate of militancy was undoubtedly J. R. de la Torre Bueno. He was a naturalized citizen, and editor of the house organ of the General Chemical Company, a firm that had twenty plants in the

\footnotetext{
E1 Ibid., 1917, pp. 235-236.

${ }^{62}$ Ibid., 1917, pp. 484-485.

asIbid., 1918, pp. 563-564.

Ibid., 1918, p. 296.
}

United States and Canada. ${ }^{65} \mathrm{He}$ assumed that foreign languages perpetuated national allegiances. In 1918 he maintained that foreigners be taught English and insisted that the nation "must do away with foreign languages" and that "the foreign language press... ought to be suppressed." To de la Torre Bueno such measures were fundamental prerequisites for a successful Americanization program. ${ }^{66}$

The staff of the Council and the majority of its members did not greet these views with enthusiasm. The Council was designing symbols to mark danger spots in factories. The alternatives for the types of symbols to be used by employers and state agencies were numerous and the factors involved in choosing symbols complex. Special committees were assigned to the task of testing and picking the most satisfactory symbols and between 1915 and 1917 they made their reports to the general membership of the Council.67 One of the questions inherent in the choice of any symbol was whether or not it conveyed its meaning to foreign-born workers. As late as 1917 no definite choices had been made, but the committee in that year clearly favored signs with captions translated for the benefit of immigrants. The chairman of the special committee stressed the need for translations. He asked his listeners to imagine themselves as workers in Poland and then confronted them with a sign carrying only a caption in Polish. The point was obvious. ${ }^{68}$

The Council also translated its safety bulletins. In 1916, a number of member firms asked the Council to help them translate safety literature or at least to provide them with names of competent

\footnotetext{
${ }^{65}$ Ibid., 1918, p. 409.

${ }^{88}$ Ibid., 1918, pp. 417-418.

${ }^{87}$ Ibid., 1917, pp. 25-37.

${ }^{68}$ Ibid., 1917, p. 37.
} 
translators. ${ }^{69}$ William H. Cameron, the general manager of the Council, told the firms that the Council hesitated to translate bulletins for three reasons: it was too expensive; it was too complicated to provide bulletins for all of the different language groups in industry; and finally, the officers of the Council were "more or less in sympathy with the Americanizers."70 However, pressure for translations from Council members prevented the Council from following militant Americanizers. In 1917, the editor of the organization's annual proceedings informed members that "if any one wants translations into any of a dozen languages they can secure this service through General Manager Cameron."71

The Council did make some efforts in developing English-language lesson plans for immigrant workers. In 1915, a special education committee asked Peter Roberts to work out special lessons devoted to safety. In the following year the Council had available for its members Englishlanguage lesson plans on such subjects as boilers, "Health and Safety," and "Safety First and Sober Always. ..."72 These lessons were similar to the ones Roberts had worked out for individual firms.

\section{SOME INDIVIDUAL RESPONSES}

Although the Council failed to support Americanization enthusiastically, its participating firms did not close their gates to Americanizers. Astute safety and welfare workers related their activities to the acculturation process. In 1916, Arthur H. Young, a former safety inspector who had recently become employment manager at

${ }^{69}$ Ibid., 1916, pp. 125-126, 365-366. B. B. Folger, chairman of the Safety Committee of the Manufacturers Association of Ludlow, Massachusetts, was among this group. Loc. cit.

${ }^{70}$ Ibid., 1916, p. 131.

TIbid.. 1917, p. 234.

72Ibid., 1916, pp. 53-54.
Illinois Steel, indicated where he stood on Americanization. He had just explained to Council members that his employment applications asked for the following information: the employee's place and date of birth and race, the place of birth and race of his parents, the number of years he had lived in the United States, naturalization status, marital status, number of offspring, the place of residence of his family, and the state of his literacy in English and in a foreign language. "I will frankly say," Young commented about these questions, "that the answers to some of... [them] are of far more interest to Uncle Sam than plant executives. ..."73 At the same time, however, Young described the relation of his own work to the acculturation process. "America," he explained, "is the melting pot she is because each industrial plant, each social settlement, and each civic center in her broad expanse, is in itself a melting pot, and the employment chief is like unto a chef, in charge of the mixture at the particular plant ... he refines a product of American manhood.... The melting pot is there and the executive who neglects a proper supervision of its activities neglects a profitable and patriotic service."74

Two visiting nurses employed by different companies described in some detail how they viewed their work with immigrants. One was Florence S. Wright who was employed by the Clark Thread Company in Newark, New Jersey. She said nothing about Americanization as such, but she did claim to be highly influential in changing the home life of an immigrant worker and in spreading the good will of the company.

I find the Italian family taking boarders. ... The father has his chest examined, is

${ }^{73}$ Ibid., 1916, p. 522.

${ }^{74}$ Ibid., 1916, p. 526. 
found to be an incipient tuberculosis case, and after a period of rest and education is given outdoor work suited to his strength. The mother is taught to buy and cook. The children are sent to an open air school. It takes time but in the end the boarders are no longer there, the father is well and doing suitable work, the children are going to school, and the mother is making a home of which the family and the nurse is proud....I have increased my Italian vocabulary and have six firm friends. Needless to say, the unseen employer who sent me also has six loyal friends, although he may never know of their existence. ${ }^{75}$

Miss Nester C. Edwards worked for the Kimberly-Clark Company in Neenah, Wisconsin, and was instrumental in placing nurses in various companies in the state and elsewhere. To her, the visiting nurse, if properly instructed for factory work, functioned as a factory social worker. She felt that it made little difference whether the original training was for nursing or social work. Successful social work in factories depended largely on only two prerequisites: the individual had first to have "the capacity and ability to take hold and get next to the individual," and needed to know the power foremen could wield. You can "never bring to the plant that healthy diffusion you want," she said, "unless you are working with the foremen's force. These are the forces to be reckoned with, your superintendent and your general management."76

She was in sympathy with the Americanization movement but pleaded that industrial interests and national interests should not be confused. English-language classes had no place in the factory, she argued, for the simple reason, that language education was not the function of

${ }^{75}$ Ibid., 1916, pp. 545-553. The quotation may be found in ibid., 1916, pp. 548-549 where it is presented in the third person singular.

${ }^{78}$ Ibid., 1917, pp. 333-334. industry but the responsibility of the public school and private organizations such as the YMCA.77 The class was an unwanted stepchild in the factory, Miss Edwards argued in the fall of 1917. "At the close of the day the group was assigned to the attic, or basement, or often crowded into the president's or board of director's office."'78

Miss Edwards charged employers with the responsibility of using their power in three ways to make workers learn English outside of the factory. First, give an increase in pay to every man who acquired a speaking knowledge of English. Second, do not promote a man until he had learned the required amount of English. Third, she said, make "it plain at the time of hiring that men and women are employed on the grounds that they will attend the night school for a required time." These methods she felt lay within the province of employer activity and were at the same time a "Safety First Measure." In order to make the pressure as effective as possible she counselled that employment secretaries or service workers keep a check on immigrants who needed to attend night school. ${ }^{79}$

It was Young, manager in 1918 of industrial relations at International Harvester, who expressed the views of those operating within the industrial framework. He insisted that immigrant workers receive special attention from employers and their service workers, not in the spirit of militant Americanization but in the spirit of the safety movement. Immigrants, he explained, "are transplanted

${ }^{77}$ Ibid., 1917, pp. 424-425.

${ }^{78}$ Ibid., 1917, p. 424.

${ }^{79} \mathrm{Ibid}$., 1917 , pp. 424-425. The use of economic power to affect the styles of life outside the workshop was not, of course, limited to immigrants. A frank statement about its use in "holding... colored labor" can be found in ibid., 1917, pp. 1294-1295. 
suddenly into the center of a very busy industrial plant from farms or street car work, or from excavation work on the streets where the hazards are entirely similar." "If we pass them through an employment office and put them on a job without instructions only natural results may be expected." Thus it was important that immigrants were interviewed in their own language, and when unable to speak or read English, to be instructed in their own language; his department had a Polish interpreter, who translated important speeches to Polish workers during wartime ceremonies. "Americanization of our foreigners, the teaching of English to them and then a higher education," said Young, "there again the educational director and the employment man must work hand in hand. Lessons can be gotten up in English on safety problems and they can be inculcated in the man's mind and part of the regular curriculum of the school." 80

\section{OTHER COMPANY PROGRAMS}

A number of large industrial organizations participated in the Americanization movement, but always on their terms and within the framework of safety and welfare programs which they had developed earlier. At the Ford School, established initially as a result of the safety movement, the first thing the immigrant learned to say was, "I am an American"; pageants dramatizing this verbal conversion had newcomers dressed in the clothing of the old world enter onto stage and then leave the stage dressed in

soIbid., 1918, pp. 785-787. Cf. with the comment Young made in 1916 when he was supervisor of labor and safety at the Illinois Steel Company. Ibid., 1916, pp. 518-520. For examples of the activities of the Polish translator, see Harvester World, vol. 10, July 1918, p. 16. For comments of safety men who shared Young's views, see National Safety Council, Proceedings: 1916, pp. 138, 627-628, 1918, pp. 528, 577.
"American" clothing. ${ }^{81}$ By the end of 1916, Ford had about 2,700 immigrants receiving language instruction from some 160 volunteer teachers using Roberts' method. The immigrant student was expected to attend classes for six to eight months before or after his work shift. At the end of his course of 72 lessons, a printed diploma qualified him for his first naturalization papers without further examination by federal authorities. ${ }^{82}$

The expansion and functioning of the school was, however, determined by the needs of the entire work force and by the firm's economic requirements. At the end of 1916, the school added mathematics, psychology, and public speaking to the curriculum. These courses were attended by about three hundred native-born workers. In the same year, the company established the Henry Ford Trade School and this institution increasingly outweighted the language school in importance in the company's educational scheme. When industrial considerations came into conflict with those of the Americanizers, the industrial ones triumphed. In 1917, during the war, the allotment of rooms for English classes was cut from 22 to 3, and after that English-language education was continued on a limited scale, with some 500 students and 30 instructors. ${ }^{83}$

When the United States Steel Corporation and a number of its subsidiaries joined the Americanization crusade, it was clear that Americanization work was but an adjunct of programs already in operation. ${ }^{84}$ As the Americanization crusade mounted in intensity, U.S. Steel's

\footnotetext{
${ }^{81}$ Higham, Strangers in the Land, p. 248.

${ }^{82}$ Nevins and Hill, Ford, vol. 1, p. 557.

${ }^{83}$ Ibid., vol. 2, pp. 340-341.

${ }^{84}$ Americanization in the steel industry is discussed in a different context by David Brody in his Steelworkers in America (Cambridge, Mass.: Harvard University Press, 1960), pp. 189-192.
} 
Bureau of Safety, Sanitation, and Welfare incorporated aspects of the crusade in its publication, but treated Americanization as something apart from safety and welfare activity. In 1916, the Bureau commented on its welfare work and noted that the Corporation's English-language education taught foreign labor "the principles of clean, wholesome living" and good citizenship. ${ }^{85}$ In 1917, immigrant education was entirely ignored, but in 1918 the Bureau devoted a special section of its bulletin to Americanization. In the issue of 1918, however, the Bureau also discussed movies used in safety work. One of these, a film made in 1912, was oriented entirely towards the immigrant but it was not discussed in the Americanization section. The Bureau described the film, about an "ignorant Hungarian peasant...stupid and uneducated" who became a forward looking, industrious workman at a plant in Gary, Indiana because of U.S. Steel's safety and welfare program, as part of its safety education. 86

In the special section of the 1918 publication, the education and Americanization of the "foreign-born workers" had become a "national problem of vital importance." It was necessary to have a "hundred percent America." The Bureau of Safety, Sanitation, and Welfare insisted that "we must help the foreign-born laborer improve the opportunities afforded to him for education and training, so that, through knowledge of the language and familiarity with the standards of living in this country his condition will be improved." 87 Now, in the midst of the Americanization crusade, the Bureau had for the moment accepted concerns outside the industrial framework. The help

\footnotetext{
${ }^{85}$ United States Steel Corporation, Committee of Safety, Bulletin, December 1916, pp. 52-53.

${ }^{86}$ Ibid., December 1918, pp. 5-6.

${ }^{87}$ Ibid., p. 95 .
}

to be given a foreign-born worker would, according to the Bureau, "awaken in him a respect for and love for American ideals which... [would] develop strong loyalty towards his adopted country. ..." 88

Subsidiary companies of the Corporation implemented Americanization work in different ways. ${ }^{89}$ Shop-language and safety-language classes were supplemented by encouraging workers to attend YMCA and public school classes. Americanization posters took their place beside safety posters. Naturalization was stressed. In one community, for example, the Americanization work of a U.S. Steel subsidiary strongly supported efforts for enabling workers to obtain naturalization papers by providing space and financial assistance to the local public schools and private groups interested in English-language lessons and civic programs. The American Bridge Company made English language lessons part of its educational program that included mathematics, mechanics, and drawing, and supplemented language instructions with "a series of pictorial charts with descriptive texts giving a sketch of, the name, use, etc. of the various tools and other objects in and around the plant." The lessons were taught by employees. The company expected English-language classes to improve the skill and "mental alertness" of the firm's immigrant workers.

The Illinois Steel Company, whose comprehensive safety program was in operation by 1913, also injected Englishlanguage classes for foreigners into its general educational program. In 1918, the company claimed that it offered the following courses: "Machine shop, Me-

\footnotetext{
${ }^{88}$ Loc. cit.

${ }^{89}$ The discussion of Americanization activities at U.S. Steel subsidiaries is based on ibid., pp. 95-103. See also National Safety Council, Proceedings: 1916 , pp. 1009-1010, 1917, pp. 237-238, 1206.
} 
chanical drawing, Electricity, English for foreigners, Shop Mathematics, Mathematics, Woodshop, [high school] English, Forge, Bookkeeping, Stenography, Chemistry, Eighth Grade." The Englishlanguage classes were run by the YMCA and, although attendance was voluntary, the instructor was required to file a form with the company indicating by number which worker was absent. Foremen would check personally on the work of the teacher as well as on the workers' attendance, and also attempted to orient the lessons of an instructor to actual operations in the company. ${ }^{90}$

The Amercian Steel and Wire Company followed similar practices but arranged for more elaborate Americanization activities at some of its plants. Two committees were created that showed a striking similarity to those characteristic of the safety organization. At the Waukegan Works of the company, a general Americanization committee was established consisting of the superintendent, the "employment man," the safety engineer, four Finns, three Austrians, three Swedes, three Lithuanians, two Armenians, two Poles, one Dane, and one German. This group arranged for three Americanization parades and four mass meetings and organized a thirty-eight piece band. Another committee was established consisting of the departmental foreman and representatives from each nationality in the department. These groups were to meet periodically and "keep in close touch with all men needing instruction in English"; they were "to help to get out their citizen papers"; they were to try "to get them to join the evening school." Provision for Englishlanguage classes at a public school were

\footnotetext{
${ }^{80}$ Interview with Howard K. Beale, 1956. The late Howard Beale was a "Y" instructor at the Illinois Steel Company in Chicago in 1918.
}

arranged through the committees of the company.

The organ of the International Harvester Company reflected the entry of Americanization into an industrial organization that had not joined the crusade at its inception. In November of 1914, two months after the outbreak of war in Europe, an editorial statement on the inside cover of the Harvester World stated the company's position about the conflict. The firm fully endorsed Wilson's policy of neutrality and stressed that one of the reasons for doing so was its many international connections. The editorial took pains to remind foreign-born employees that they were American citizens, but recognized explicity that it was only natural for an immigrant to favor his country of origin. Nevertheless, the firm stressed that "this country and this company has only one interest in the present struggle; an early termination of hostilities."91 Between November 1914 and the eve of America's entry into battle, little was said about the war or Americanization. Only once in this period did the house organ indicate that there was concern about Americanization. The exception, however, was not without significance, for it was in the safety and welfare section of the journal and referred to activities at the Weber Works, a plant that had begun English-language classes in 1912.

In May 1916, the foremen's club at the Weber Works decided to assist employees of foreign nationality to become citizens. On the suggestion of the plant superintendent, the Club established a special committee to make a survey of those who had not made applications for first papers, and to check on the progress of those in the process of obtaining first and

${ }^{91}$ Harvester World, vol. 5, November 1914 , inside front cover. 
second papers. ${ }^{92}$ In order to facilitate filing procedures for naturalization, the committee arranged with the clerk of the Superior Court of Cook County to meet the applicant group in a body at a time and place so arranged as to prevent loss of wages. All this was done in the name of the community and country. "Although the [foremen's] club feels that... the work may be slow," said Harvester World, "yet it feels that it is demanded by the best interest of the city and the nation." "93

Following this report, there was no further reference to Americanization activity until February 1917, but then news of Americanization work came often. During the war, other works besides the Weber plant sought to increase the number of citizens among their employees and "do their bit" for teaching immigrants English. The Keystone Works announced with great pride to readers of Harvester World that all but two of the Works' immigrants had become naturalized or had taken out their first papers. ${ }^{94}$ Keystone had also established an English-language class in one of the offices to which immigrants came two evenings a week for one-and-a-half hours. Following classes, a mock naturalization court was conducted in the hope that applicants for citizenship could gain some experience with naturalization proceedings. According to a spokesman of Keystone, the following dialogue was typical of exchanges between the "judge" and the "applicant."

Teacher: Who was the first president of the United States?

Alien: George da Wash.

Teacher: Who is president now?

${ }^{92}$ Ibid., vol. 7, May 1916, p. 30.

${ }^{93}$ Loc. cit.

${ }^{94}$ F. F. Trigg, "Keystone Works-100 Percent American," in ibid., vol. 9, June 1918, p. 8.
Alien: Mr. da Wils.

Teacher: Could you be president?

Alien: Excuse me please, I got pretty good job on the Keystone. $^{95}$

By the summer of 1918, classes for English and citizenship had become characteristic of numerous branches of the International Harvester Company. This was particularly so in the Chicago area. Some of the factories there conducted classes themselves during two noon hours of the work week. At other units, the classes were handled by the YMCA. In St. Paul, the company had teachers come to the factory for twenty minutes during the noon hour. ${ }^{96}$ The use of YMCA personnel in 1918 was explained by the Harvester World. It had been found that "when the YMCA conducted these classes the results were better than when English courses were part of the regular shop schools." "97 Special campaigns for naturalization similar to those begun by the Weber Works were now also conducted by other installations of the company. The Deering Works, for example, used the questionnaire method for determining the number of citizens among its workers and used its club-house facilities for issuing first papers. ${ }^{98}$

News about Americanization was usually printed in the safety and welfare section of the Harvester World and was often accompanied by pictures of employees surrounded with a maze of flags. A two-page spread showed special ceremonies using the various patriotic symbols. The journal printed pictures of work rooms bedecked with flags and

${ }^{95}$ Ibid., pp. 8-9.

${ }^{\circledR}$ Ibid., vol. 9, July 1918, p. 13; A. E. Conrath, International Harvester Company, St. Paul, Minnesota, in National Safety Council, Proceedings, 1918, pp. 582-583.

${ }^{97}$ Harvester World, vol. 9, July 1918, p. 13.

${ }^{8 s}$ Loc. cit. 
often noted that most of the employees who had done the decorating were of foreign birth. Liberty-bond drives were publicized by reporting how this or that plant had gone "over the top" of its goal. The campaign of Herbert Hoover to conserve food was announced by a full-page spread that included a facsimile of the conservation pledge that was being distributed by the government. The Harvester World also reproduced pictures of plant honor boards dedicated to men in military service, and printed news about employees sending Christmas packages to the front. ${ }^{99}$

All these news items about war activity in the plants were in keeping with tactics found useful by house organ editors in attracting readers in the work force. The editor of the Harvester World, as well as editors of other company house organs, was trying to personalize the war effort as much as possible in order to inject another common denominator into the work force. By 1918, Americanization and other war activities had been linked together and formed " $100 \%$ Americanism." House organ editors assumed that a worker's enthusiastic participation in " $100 \%$ Americanism" would aid in producing harmonious relations within the shop and would stimulate production. ${ }^{100}$

The Harvester World, as did other company organs, also printed editorials and super-patriotic speeches in its campaign for " $100 \%$ Americanism." An editorial in August 1918, for example, concerned itself with nominations of candidates seeking re-election to Con-

\footnotetext{
${ }^{80}$ Ibid.: vol. 8, September 1917 , pp. 5-7, 17, October 1917, pp. 12-13, 16, vol. 9, February, 1918, pp. 9, 11, March 1918, p. 10, July 1918, pp. 16-17.

${ }^{100}$ For a frank discussion by house organ editors of the methods they used, see "The Employee's Publication," round-table discussion in National Safety Council, Proceedings, 1918, pp. 409-430. See also ibid., pp. 345-346.
}

gress. The journal insisted that only those men should be nominated who were loyal and patriotic. "If a weak or a bad man sits in the next Congress-a stupid man, a mere self seeker, or a shifty sneaking pacifist-" said the journal, "the blame will be on his district." 101 This political appeal may have been motivated in part by the fact that the controversial socialist, Victor Berger, was then seeking re-election from the Fifth Congressional District in Milwaukee, a city in which the International Harvester Company had an important plant.

It was from this plant, where Englishlanguage classes and naturalization exercises were not in operation, that the journal received a bombastic appeal for "100\% Americanism." In September 1918, the Harvester World printed the speech to Milwaukee workers in which Paul Schryer, the superintendent, appealed to the plant's employees to go "over the top" in the fourth liberty-bond drive. ${ }^{102}$

To dramatize the appeal, Schryer's talk was preceded by flag-raising ceremonies, and the superintendent then built his address around the flag and the men at the front fighting in defense of the nation. He inferred that many in his work force had sided with the Central Powers before America had joined the conflict. "As I told the boys here last night... it is immaterial now as to who started the war. We are not going to take any time talking about that, but I am sure of one thing," shouted Schryer, "and that is, who is going to finish the war. There is but one answer - America." $\mathrm{He}$ pounded out the theme of the need for $100 \%$ participation in the bond drive. "I will be very much disappointed if I cannot call up our Chicago office... and re-

\footnotetext{
${ }^{101}$ Harvester World, vol. 9, August 1918, p. 3.
} ${ }^{102}$ Ibid., vol. 9, October 1918, p. 10. 
port that Milwaukee Works' employees are not simply loyal but are absolutely 100 percent loyal." In closing his appeal, he reiterated part of a statement that he had made at the beginning. One employee recalled many years later that German and Hungarian workmen huddled in corners after the superintendent said this: "If there is one man in this organization who would hesitate to contribute to alleviate or lessen the suffering of... [ the men at the front] I would advise him to go somewhere out on the prairie away from the gaze of civilization and drain the yellow blood out of his heart."103

For the Harvester World, the printing of Schryer's appeal marked the high point of its $100 \%$ Americanism. Following the end of hostilities, the journal reported on the continuation of Americanization classes in the various works of the company. ${ }^{104}$ While the years of 1919 and 1920 brought a fresh impetus to such activities, the journal's tone changed rather drastically. In 1919, Harvester World printed and applauded statements about Americanization that criticized the aim and premise of $100 \%$ Americanism and editorially questioned the merits of militancy. It gave much publicity to its industrial council plan that, according to the house organ, would provide the "machinery for solving differences between management and labor and also give workers a share in the planning and execution of matters in their immediate interest." 105 International Harvester had

\footnotetext{
${ }^{103}$ The writer had asked the employee, over 65 years old, what he remembered about the days of World War I. The first thing that came to his mind was Schryer's talk. Interview with A. F. Leidel, 1956.

${ }^{104}$ Harvester World: vol. 10, July 1919, pp. 8, 11, October 1919, p. 9, vol. 11, April 1920, p. 11.

${ }^{105}$ Ibid., vol. 10, March 1919, p. 10; Cyrus McCormick, Jr., "Cooperation and Industrial Progress," address to the National Safety Council, Proceedings, 1919, pp. 40-50. This address was
}

also embarked on a program that resulted in an industrial relations department and a broadening of existing industrial service work, and had joined the InterRacial Council of Frances Kellor. ${ }^{106}$

\section{CONCLUSION}

Harvester World's change in posture reflected changes in Miss Kellor's viewpoints and activities. With the end of the war, she had returned to non-governmental agencies in her efforts to link Americanization to "harmonizing efforts." The return of peace rapidly brought to an end the war-time agencies engaged in Americanization, and also saw the Bureau of Education withdraw from the field. ${ }^{107}$ The only federal agency remaining in Americanization work was the Bureau of Naturalization and Immigration, and this Bureau was interested only in conducting work for immigrants through the public schools. ${ }^{108}$ Her new organization became the Inter-Racial Council, a direct descendant of the Committee of Immigrants in America that had also disbanded with the end of the conflict.

The new group, founded in late November 1918, soon represented hundreds of industrial corporations with Miss Kellor serving as the chief executive officer. Until the depression of 1921 ended the Council's life, the group was preoccupied with the spector of Bolshevism and with the related problem of gaining a tighter grip on the industrial loyalties of immigrant workers; ${ }^{109}$ this problem had been

reprinted in Harvester World. See also ibid., vol. 10, August 1919, pp. 1-2.

${ }^{108}$ Cyrus McCormick, Jr., "The Advantages of a Superintendent of Labor," in ibid., vol. 9, April 1918 , p. 4; ibid., inside front cover; ibid., vol. 11, December 1920, p. 24; Hartman, Movement to Americanize the Immigrant, p. 220, n. 7.

${ }^{107}$ Ibid., pp. 228-234.

${ }^{108}$ Ibid., pp. 236-237.

${ }^{109}$ Ibid., pp. 220-225; Higham, Strangers in the Land, p. 257. 
accentuated by the Steel Strike of 1919 . Miss Kellor's work became fully integrated with managerial efforts to systematize human relations in factories in the interests of industrial stability and harmony. She dropped the shrill tones of militant nationalism and turned to techniques of veiled coercion in order to convince immigrants not to act against the interests of their employers. Among her methods was the utilization of the immigrant press for achieving her ends diplomatically. She gained control of the American Association of Foreign Language Newspapers and was able to flood the immigrant press with "patriotic articles, admonitions against emigration to Europe, and anti-radical propaganda." 110

It is "essential to develop in the foreign-language press a friendly interest in

\footnotetext{
${ }^{110}$ Ibid., pp. 257-258.
}

American affairs," she told the convention of the National Association of Manufacturers in 1920, "an attitude that is pro-American." "I believe it to be one of the best antidotes to Bolshevism, that when any thing good is being done in industry, the story of it should be told in the foreign-language press, so that these men get something besides attacks on capital. ...We think it is one of the most practical ways of reaching these people and getting them interested in Americanism."111 Frances Kellor, once a New Nationalist progressive, then a militant Americanizer, had now become a spokesman for the industrial relations of welfare capitalism, promoted through the power of corporations to impose "educational" programs on workers.

${ }^{11}$ Quoted in Hartman, Movement to Americanize the Immigrant, pp. 222-223. 